\title{
Evaluation of Stoichiometry, Stability Constants and Gibbs Free Energies of Acetaminophen-Zn (II) complex at Different Temperatures
}

\author{
${ }^{1}$ IKPEAZU, OV;*2OTUOKERE, IE; ${ }^{3}$ IGWE, KK \\ 'Department of Biochemistry, Abia State University Uturu, Nigeria \\ ${ }^{* 2}$ Department of Chemistry, Michael Okpara University of Agriculture, Umudike, Nigeria \\ ${ }^{3}$ Department of Vet. Biochemistry and Animal Production, Michael Okpara University of Agriculture, Umudike, Nigeria \\ *Corresponding Author Email: ifeanyiotuokere@gmail.com; Tel: +2347065297631
}

\begin{abstract}
Acetaminophen also known as paracetamol, is a drug used in the treatment of pain and fever. It is essentially used for the relief of mild to moderate pain. The presence of phenol and carbonyl oxygen atom enables acetaminophen to behave as a bidentate ligand. The stoichiometry, stability constants and Gibbs free energies of acetaminophen-Zn (II) were determined colorimetrically at 25 and $40{ }^{\circ} \mathrm{C}$ using continuous variation and mole ratio methods. The formation of $\mathrm{Zn}$ (II) complex with acetaminophen was studied colorimetrically at an absorption maximum of $630 \mathrm{~nm}$ at different temperatures. The data showed that $\mathrm{Zn}$ (II) and acetaminophen combine in the molar ratio of 1:1 at $\mathrm{pH} 7.4$ with ionic strength maintained using $0.1 \mathrm{M} \mathrm{KNO}_{3}$. Calculated stability constants values were $2.70 \times 10^{3}$ and 2.20 $\times 10^{3}$ using continuous variation method and $7.21 \times 10^{3}$ and $7.21 \times 10^{3}$ using mole ratio methods at 25 and $40{ }^{\circ} \mathrm{C}$ respectively. Calculated $\Delta \mathrm{G}^{\Theta}$ for the complex were $-1.96 \times 10^{4}$ and $-1.98 \times 10^{4} \mathrm{~J}$ using continuous variation method and $-2.2 \times 10^{4} \mathrm{~J}$ and $-2.31 \times 10^{4} \mathrm{~J}$ using mole ratio method at 25 and $40{ }^{\circ} \mathrm{C}$ respectively. The stability constant and Gibbs free energy results suggested that acetaminophen used in the study is a good chelating agent and can be an efficient antidote in the therapy of $\mathrm{Zn}$ (II) overload or poisoning.
\end{abstract}

\section{DOI: https://dx.doi.org/10.4314/jasem.v24i7.3}

Copyright: Copyright $(\mathrm{C} 2020$ Ikpeazu et al. This is an open access article distributed under the Creative Commons Attribution License (CCL), which permits unrestricted use, distribution, and reproduction in any medium, provided the original work is properly cited.

Dates: Received: 11 May 2020; Revised: 22 June 2020; Accepted: 07 July 2020

Keywords: Acetaminophen, Zinc, complex, stability constant, Gibbs free energy.

Acetaminophen (Figure 1) also known as paracetamol, is a drug used in the treatment of pain and fever (Lee, 2017). It is essentially used for the relief of mild to moderate pain (ASHSP, 2016). Report has shown that it is use to relieve fever in children (Meremikwu and OyoIta, 2002; de Martino and Chiarugi, 2015). It is often sold in combination with other cold medications for relieve of cold (ASHSP, 2016). Acetaminophen is also used for the treatment of severe pain, such as cancer pain and pain after surgical operation, in combination with opioid pain medication (SIGN, 2008). It is administered orally but can also be administered intravenously (Hochhauser, 2014). The analgesic effects last between two and four hours (Hochhauser, 2014). Acetaminophen is generally safe within the recommended doses (Russell et al., 2003; Machado et al., 2005). The recommended maximum daily dosage for an adult is 3-4 grams (Machado et al., 2005). Higher dosage causes liver failure (ASHSP, 2016) and serious skin reaction (ASHSP, 2016). It is relatively safe during pregnancy and during breastfeeding (ASHSP, 2016). It may be administered at lower doses to those with liver disease (Lewis and Stine, 2013). It is categorized as a mild analgesic (Hochhauser, 2014). It does not possess significant anti-inflammatory activity (McKay and Walters, 2013). It has no clear mechanism of action (McKay and Walters, 2013;
Ghanem, et al., 2016; Viswanathan et al., 2008). Zinc is involved in several cellular metabolic processes (Classen et al., 2011). It was evaluated that $10 \%$ of human proteins chelate to zinc. Hundreds of human proteins also transport and traffic zinc. It was reported that over 200 enzymes require $\mathrm{Zn}$ for their catalytic activity (Sandstead, 1994) and it plays a role in immunity, healing of wounds, synthesis of protein, DNA and cell division (Prasad, 1995). Zinc is essential for proper sense of taste and smell (Prasad et al., 1997) and it also assist normal growth and development during pregnancy, childhood, and adolescence (Milbury and Richer, 2008). It possesses antioxidant properties that protect against accelerated aging and assist in healing process after an injury; however, studies on its effectiveness differs (Maret and Sandstead, 2006). Synthesis, characterization and evaluation of anti-inflammatory activity of acetaminophen complex of Zinc (II) ions have been reported (Faruna et al., 2017). The complex (Figure 2) was synthesized and characterized by FTIR, UV- Visible spectroscopy, x-ray diffraction analysis, and melting point and conductivity measurements. On the basis of their study, it is proven that acetaminophen acted as a bidentate ligand coordinating to $\mathrm{Zn}$ ions through phenol and carbonyl oxygen atom. Synthesis and solid-state characterization of $\mathrm{Zn}$ (II) metal complex with 
acetaminophen have been reported (Ledeti et al., 2013). For several decades, chelating agents have been used as antidote to combat metal poisoning (Tella and Obaleye, 2010). Biological friendly complexing agents have been used effectively to chelate metals in patients with metal overload (Tella and Obaleye, 2010). Many authors have reported the study of stability constant of drug- metal complexes (Reková, et al., 2009; Tirmizi, et al., 2008; Tirmizi, et al., 2012). However, to the best of authors' knowledge, stoichiometry mole fraction, stability constants and Gibbs free energies of acetaminophen $-\mathrm{Zn}$ (II) complex at different temperatures have yet not appeared in the literature. These stability constants are useful to study the effects of acetaminophen on trace metals and mineral metabolism. It is possible that changes in trace metal and mineral concentration induced by acetaminophen can be an efficient antidote in the therapy of $\mathrm{Zn}$ overload or poisoning. In this context, the aim of this study was to assess stoichiometry, stability constants and Gibbs free energies change of acetaminophen - Zn (II) complex at 25 and $40{ }^{\circ} \mathrm{C}$ respectively.

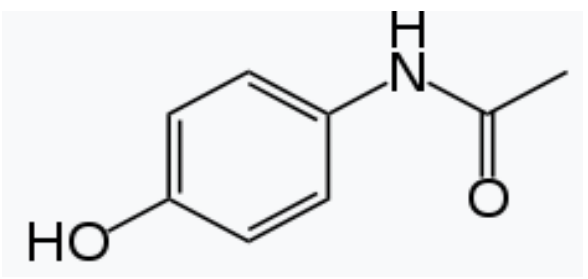

Fig 1: Chemical structure of acetaminophen

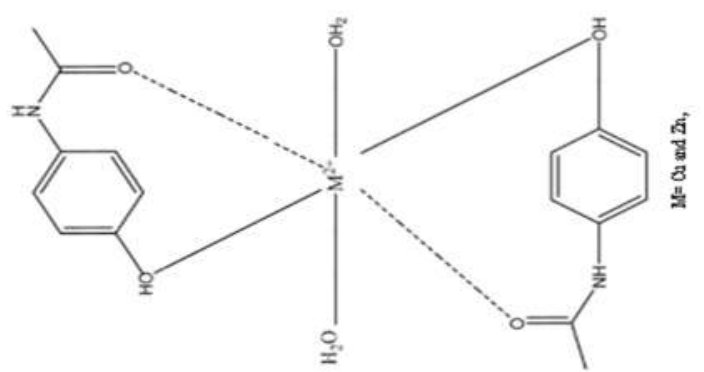

Fig 2: Tentative structure of acetaminophen metal complexes, $\mathrm{M}=$ $\mathrm{Cu}$ (II) and Zn (II) (Ledetiet al., 2013; Farunaet al., 2017)

\section{MATERIALS AND METHODS}

Instrumentation:Orion Versa Star Pro $\mathrm{pH}$ Benchtop meter (VSRAR10 series) was used for $\mathrm{pH}$ determination. Colorimetric measurements were performed on auto colorimeter ME-51.

Reagents: All reagents used were of analytical grade purity. Acetaminophen was purchased from CSPC Zhongnuo Pharmaceutical Company Limited, Shijiazhuang, China. $\mathrm{ZnCl}_{2}$ was purchased from Merck Germany. Double-distilled water was used throughout the experiment.
Preparation of $1 \times 10^{-2} \mathrm{M} \mathrm{ZnCl}_{2}: \mathrm{ZnCl}_{2}(1.362 \mathrm{~g}, 10 \mathrm{M}$ mol, M. Wt. $=136.290 \mathrm{~g} / \mathrm{mol}$ ) was dissolved in freshly distilled in a $250 \mathrm{~cm}^{3}$ beaker and was made up to the mark in a $1000 \mathrm{~cm}^{3}$ volumetric flask.

Preparation of $1 \quad x \quad 10^{-2} \quad M$ acetaminophen: Acetaminophen $(1.511 \mathrm{~g}, 10 \mathrm{~m} \mathrm{~mol}$, M. Wt. $=151.163$ $\mathrm{g} / \mathrm{mol}$ ) was dissolved in freshly distilled in a $250 \mathrm{~cm}^{3}$ beaker and was made up to the mark in a $1000 \mathrm{~cm}^{3}$ volumetric flask.

Procedure for continuous variation method: $\mathrm{ZnCl}_{2}(1 \mathrm{x}$ $\left.10^{-2} \mathrm{M}\right)\left(0,1,2,3,4,5,6 \mathrm{~cm}^{3}\right)$ was pippeted out and transferred into seven $50 \mathrm{~cm}^{3}$ volumetric flasks. Acetaminophen $\left(1 \times 10^{-2} \mathrm{M}\right)\left(6,5,4,3,2,1,0 \mathrm{~cm}^{3}\right)$ was added, respectively to the $\mathrm{Zn}$ (II) solution so that the mole fraction remained constant. The $\mathrm{pH}$ adjusted to 7.4 and ionic strength maintained constant by using $0.1 \mathrm{M}$ $\mathrm{KNO}_{3}$. Their absorbance were measured at $630 \mathrm{~nm}$ (maximum absorbance of the complex) and at a temperature of 25 and $40{ }^{\circ} \mathrm{C}$, respectively. Procedure for mole ratio method: $\mathrm{ZnCl}_{2}\left(1 \mathrm{x} 10^{-2} \mathrm{M}\right)\left(2 \mathrm{~cm}^{3}\right)$ was pippeted out and transferred into each of the seven 50 $\mathrm{cm}^{3}$ volumetric flasks. Acetaminophen $\left(2 \times 10^{-2} \mathrm{M}\right)(1$, $2,3,4,5,6,7 \mathrm{~cm}^{3}$ ) was added to each of the $\mathrm{Zn}$ (II) solution respectively. Their absorbance was measured at $630 \mathrm{~nm}$ (maximum absorbance of the complex) and at a temperature of 25 and $40{ }^{\circ} \mathrm{C}$, respectively.

Calculation of stoichiometry mole fraction, stability constant and free energy: The stoichiometry mole fraction (SMF) of the complex using continuous variation method was calculated using equation 1 (Abbas, 2017)

$$
S M F=\frac{m}{1-m} 1
$$

Where $\mathrm{m}$ is the mole fraction of metal ion.

Equation 2 (Abbas, 2017) was applied to the calculation of stability constant.

$$
K_{\text {Stability }}=\frac{1-\alpha}{m^{m} \cdot n^{n}(\alpha)^{m+n}(C)^{m+n-1}} \quad 2
$$

Where $\mathrm{C}$ is the concentration of the complex at stoichiometry point, $\alpha$ is the degree of dissociation, $\mathrm{m}$ and $\mathrm{n}$ are the corresponding stoichiometric coefficients of metal and ligand respectively.

The degree of dissociation $(\alpha)$ was calculated using equations 3, 4 and 5 (Abbas, 2017)

$$
\begin{array}{ll}
A_{\alpha}=A_{o}-A_{\max } & 3 \\
A_{\max }=\varepsilon b C & 4 \\
\alpha=\frac{A_{\alpha}}{\varepsilon b C} & 5
\end{array}
$$


Where $A_{\max }$ is absorbance value of the maximum at experimental curve that represents the maximum quantity of the complex that is formed. $A_{o}$ is absorbance value corresponding to the intersect point of the theoretical straight lines. $A_{\alpha}$ is the absorbance value of the part of dissociated concentration of complex. $\varepsilon$ is molar absorptivity, $\mathrm{b}$ is cell thickness, $\mathrm{C}$ is a concentration of complex at stoichiometry point.

The Gibbs free energy was calculated using equation 6.

$$
\Delta G^{\theta}=-R T I n K_{\text {stability }} \quad 6
$$

\section{RESULTS AND DISCUSSION}

The absorption spectra (Figure 3) shows the absorbance of $\mathrm{ZnCl}_{2}$ (series 1) and acetaminophene- $\mathrm{Zn}$ (II) complex (series 2) at wavelength of $400-670 \mathrm{~nm}$. The wavelength of maximum absorbance of the complex was
$630 \mathrm{~nm}$. At the wavelength, $\mathrm{ZnCl}_{2}$ have a weak absorbance. Therefore, this wavelength was used for the measurement of absorbance in the determination of the stability constants and free energies. $\mathrm{ZnCl}_{2}$ absorbs maximally at wavelength of $670 \mathrm{~nm}$. It was observed that acetaminophen-Zn (II) complex gave a water soluble complex. In aqueous solution, $\mathrm{Zn}$-aquo complex is a labile complex because water behaved as a weak ligand. Acetaminophen displaced water from $\mathrm{Zn}$-aquo to form a stable acetaminophen - Zn (II) complex. Similar labile aquo complexes were also reported by Tirmizi and coworkers in their study of famotidine-Cu complex and cimetidine-Ni complex. (Reková, et al., 2009; Tirmizi, et al., 2008; Tirmizi, et al., 2012). Tella and co-workers reported labile aquo complex in their study of Dapsone$\mathrm{Cu}(\mathrm{II})$ stability constants (Tella and Obaleye, 2009). The absorption spectra of acetaminophen-Zn (II) complex is shown in Figure 3

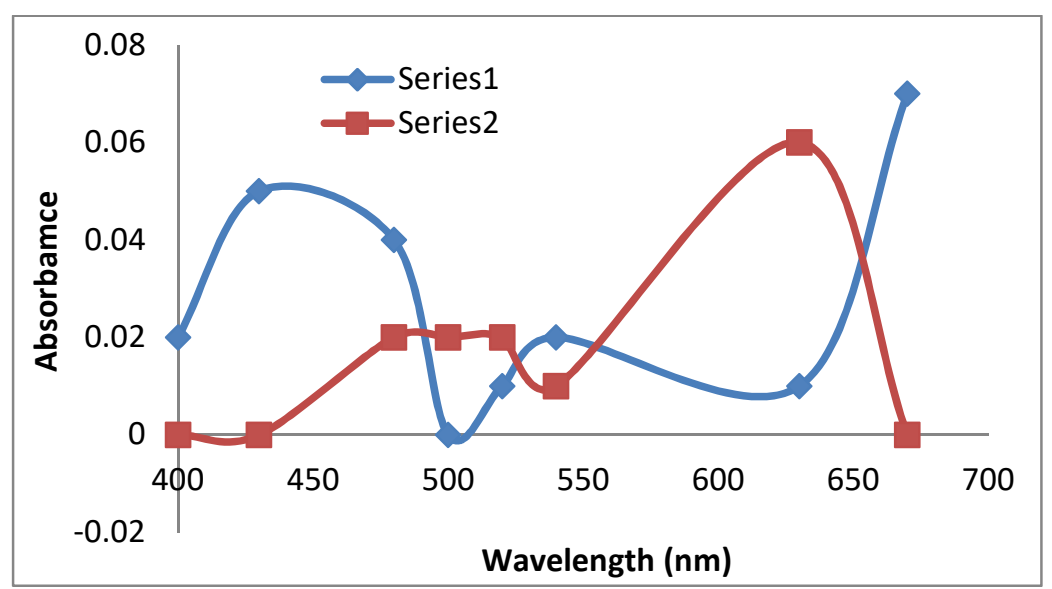

Fig 3: Absorption spectra of $\mathrm{ZnCl}_{2}\left(1 \times 10^{-2} \mathrm{M}\right)$ (series 1) and acetaminophene-Zn (II) complex $\left(1 \times 10^{-2} \mathrm{M}\right)$ (series 2)

Table 1: Experimental data of acetaminophen-Zn(II) complex at $630 \mathrm{~nm}$ by continuous variation method

\begin{tabular}{|c|c|c|c|c|c|}
\hline \multirow[t]{2}{*}{$\mathrm{S} / \mathrm{N}$} & \multirow{2}{*}{$\begin{array}{l}\mathrm{ZnCl}_{2} \\
\left(1 \times 10^{-2} \mathrm{M}\right)\end{array}$} & \multirow{2}{*}{$\begin{array}{l}\text { Acetaminophen } \\
\left(1 \times 10^{-2} \mathrm{M}\right)\end{array}$} & \multirow{2}{*}{$\begin{array}{l}\text { Mole fraction of } \\
\mathrm{Zn}(\mathrm{II})\end{array}$} & \multicolumn{2}{|c|}{ Absorbance at $630 \mathrm{~nm}$} \\
\hline & & & & $25^{\circ} \mathrm{C}$ & $40^{\circ} \mathrm{C}$ \\
\hline 1 & 0.00 & 6.00 & 0.00 & 0.01 & 0.01 \\
\hline 2 & 1.00 & 5.00 & 0.17 & 0.02 & 0.02 \\
\hline 3 & 2.00 & 4.00 & 0.33 & 0.02 & 0.03 \\
\hline 4 & 3.00 & 3.00 & 0.50 & 0.04 & 0.04 \\
\hline 5 & 4.00 & 2.00 & 0.66 & 0.03 & 0.03 \\
\hline 6 & 5.00 & 1.00 & 0.83 & 0.01 & 0.01 \\
\hline 7 & 6.00 & 0.00 & 1.00 & 0.01 & 0.01 \\
\hline
\end{tabular}




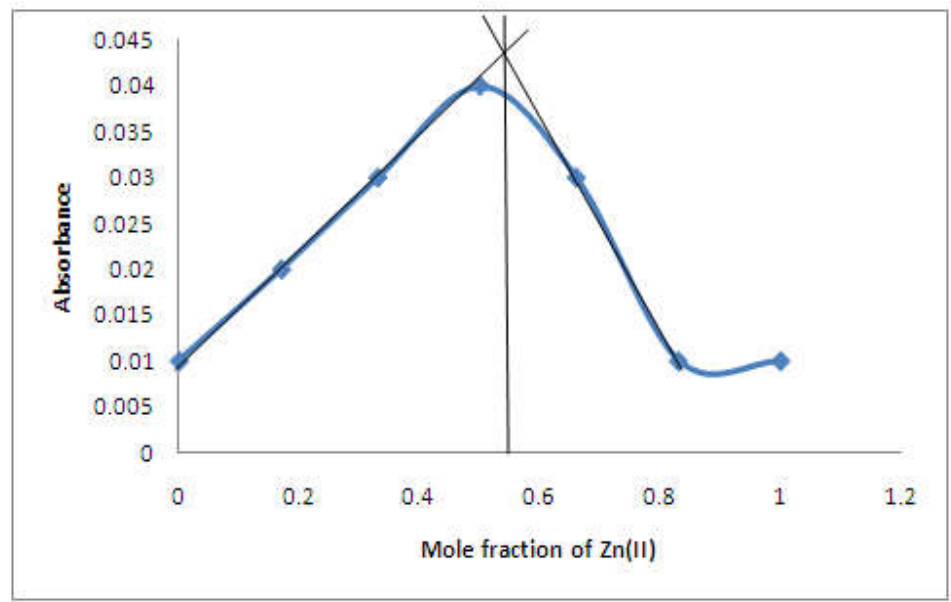

Fig4: Job's curves for stability constants of equimolar solutions at $25^{\circ} \mathrm{C}$

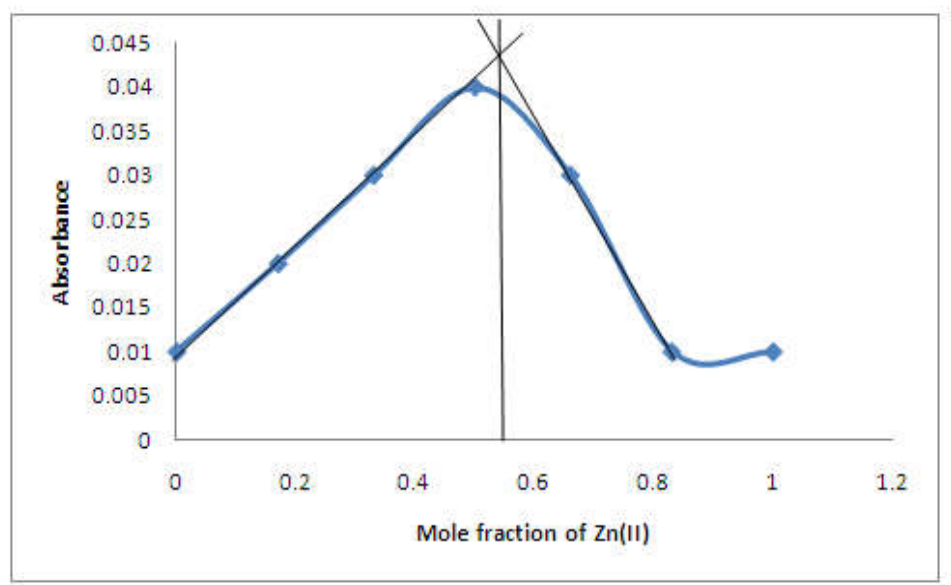

Fig 5: Job's curves for stability constants of equimolar solutions at $40{ }^{\circ} \mathrm{C}$

Application of equation $1, S M F=\frac{0.55}{0.45}=1.22 \approx 1$ (at $\left.25^{\circ} \mathrm{C}\right)$ and $S M F=\frac{0.55}{0.45}=1.22 \approx 1\left(\right.$ at $\left.40{ }^{\circ} \mathrm{C}\right)$. The mole fraction of $\mathrm{Zn}(\mathrm{II})$ at the point of intersection are 0.55 and 0.55 at 25 and $40{ }^{\circ} \mathrm{C}$ respectively The extrapolated value at the point of cross-section on continuous variation plot (Figures 4 and 5) corresponded to the total absorbance of the complex, indicating that the complex formation process has been completed. This corresponded to metal:ligand ratio of 1:1. Several authors have also applied continuous variation method in the determination of metal:ligand ratio in complexes (Reková, et al., 2009; Tirmizi, et al., 2008; Tirmizi, et al., 2012).

Table 2: Experimental data of acetaminophen-Zn (II) complex at $630 \mathrm{~nm}$ by mole ratio method

\begin{tabular}{|c|c|c|c|c|c|}
\hline \multirow[t]{2}{*}{$\mathrm{S} / \mathrm{N}$} & \multirow{2}{*}{$\begin{array}{l}\mathrm{ZnCl}_{2} \\
\left(1 \times 10^{-2} \mathrm{M}\right)\end{array}$} & \multirow{2}{*}{$\begin{array}{l}\text { Acetaminophen } \\
\left(1 \times 10^{-2} \mathrm{M}\right)\end{array}$} & \multirow{2}{*}{$\begin{array}{l}\text { Vol of } \\
\text { acetaminophen } \\
\text { / vol. of } \mathrm{Zn}(\mathrm{II})\end{array}$} & \multicolumn{2}{|c|}{ Absorbance at $630 \mathrm{~nm}$} \\
\hline & & & & $25^{\circ} \mathrm{C}$ & $40^{\circ} \mathrm{C}$ \\
\hline 1 & 2.00 & 1.00 & 0.50 & 0.018 & 0.018 \\
\hline 2 & 2.00 & 2.00 & 1.00 & 0.020 & 0.020 \\
\hline 3 & 2.00 & 3.00 & 1.50 & 0.020 & 0.020 \\
\hline 4 & 2.00 & 4.00 & 2.00 & 0.020 & 0.020 \\
\hline 5 & 2.00 & 5.00 & 2.50 & 0.020 & 0.020 \\
\hline 6 & 2.00 & 6.00 & 3.00 & 0.020 & 0.020 \\
\hline 7 & 2.00 & 7.00 & 3.50 & 0.020 & 0.020 \\
\hline
\end{tabular}




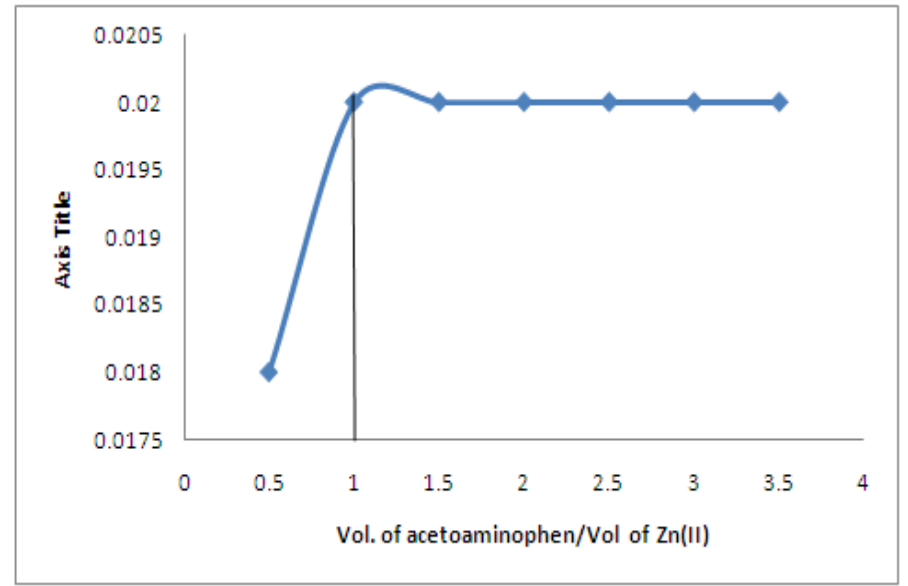

Fig 6: Mole ratio method curves for stability constant at $25{ }^{\circ} \mathrm{C}$

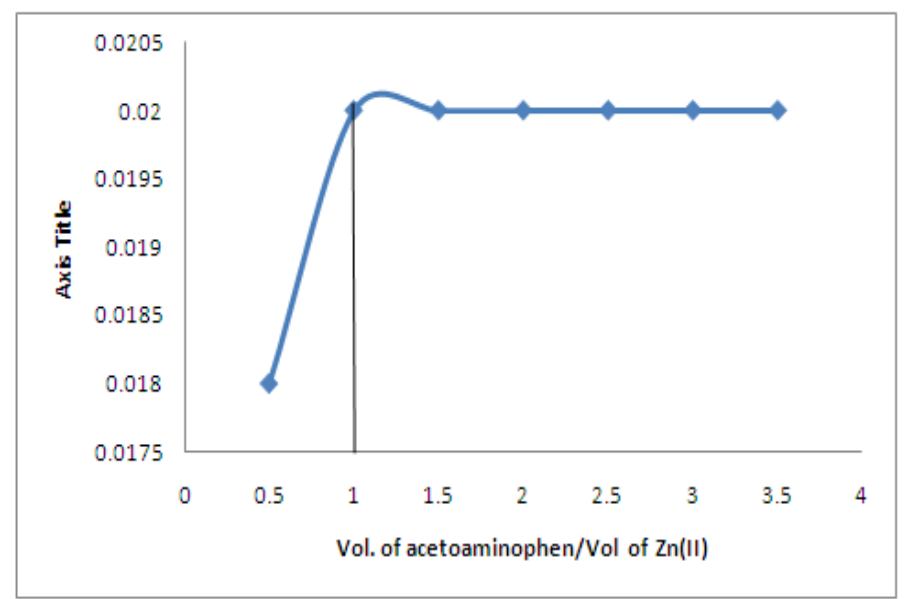

Fig 7: Mole ratio method curves for stability constant at $40{ }^{\circ} \mathrm{C}$

The vol. of acetaminophen/vol. of $\mathrm{Zn}$ (II) at the point of intersection are 1.0 and 1.0 at 25 and $40{ }^{\circ} \mathrm{C}$ respectively. The extrapolated value at the point of cross-section on mole ratio plot (Figures 6 and 7) corresponded to the total absorbance of the complex, indicating that the complex formation process has been completed. The stoichiometry ratio of the complex was evaluated from the point where this curve changes its slope. This corresponded to metal:ligand ratio of $1: 1$. Mole ratio method is an established technique in the determination of stoichiometry of metal complexes (Reková, et al., 2009; Tirmizi, et al., 2008; Tirmizi, et al., 2012).

Table 3: Calculated values of stability constant and Gibbs free energies

\begin{tabular}{|c|c|c|c|c|c|c|}
\hline \multirow[t]{3}{*}{ S.No } & \multirow[t]{3}{*}{ Method } & \multirow{3}{*}{$\begin{array}{l}\text { Metal: } \\
\text { ligand } \\
\text { ratio }\end{array}$} & \multicolumn{4}{|c|}{ Stability constant } \\
\hline & & & \multicolumn{2}{|c|}{$\Delta \mathbf{G}^{\boldsymbol{\theta}}$} & \multicolumn{2}{|c|}{ (J) } \\
\hline & & & $25^{\circ} \mathrm{C}$ & $40^{\circ} \mathrm{C}$ & $25^{\circ} \mathrm{C}$ & $40^{\circ} \mathrm{C}$ \\
\hline 1 & Continuous variation & $1: 1$ & $2.70 \times 10^{3}$ & $2.00 \times 10^{3}$ & $-1.96 \times 10^{4}$ & $-1.98 \times 10^{4}$ \\
\hline 2 & Mole ratio & $1: 1$ & $7.21 \times 10^{3}$ & $7.21 \times 10^{3}$ & $-2.20 \times 10^{4}$ & $-2.31 \times 10^{4}$ \\
\hline
\end{tabular}

The results of stability constant suggested that acetaminophen could be effective in chelation therapy against $\mathrm{Zn}(\mathrm{II})$ toxicity. The negative values of the free energies suggested that the complexes were formed spontaneously.Continuous variation and mole ratio methods are established techniques in the determination of stability constant and Gibbs free energies. The stability constant and Gibbs free energies were calculated by applying equations $2,3,4,5$ and 6 . The stability constant values showed that the complex was stable both at room temperature and higher temperature. The values of the stability constants obtained from continuous variation compared well with that of mole ratio method. It can be seen from the Table 3 that the 
values obtained by both methods are in fair agreement. Increasing the temperature of chelation form 25 to $40{ }^{\circ} \mathrm{C}$ had no effect on the stability constant. The values of the stability constants were positive; this suggested that the complex was stable. Similar positive values of stability constant of complexes were reported by Tirmizi and coworkers (Tirmizi, et al., 2008; Tirmizi, et al., 2012) using continuous variation and mole ratio methods. Waranyoupalin and co-workers also reported positive stability constant values using continuous variation and mole ratio methods (Waranyoupalin, 2009).

Conclusion:The Job's continuous variation and mole ratio methods data showed that $\mathrm{Zn}$ (II) and acetaminophen combine in the molar ratio of $1: 1$. Job's method of analysis corresponded well with the values obtained using mole ratio method of analysis. The stability constants and free energies results suggested that acetaminophen used in the study is a good chelating agent and can be an efficient antidote in the therapy of $\mathrm{Zn}(\mathrm{II})$ overload or poisoning.

\section{REFERENCES}

Abbas, RF (2017). Spectrophotometric determination of stability constant by classical and Modified Varagas equations for procaine penicillin $G$ using diazotization reaction depending on stoichiometric curves, Int. J. of ChemTech Res. 10 (2): 485 - 496.

Classen, HG; Gröber, U; Löw, D; Schmidt, J; Stracke, H (2011) Zinc deficiency: Symptoms, causes, diagnosis and therapy. Med Monatsschr Pharm, 34: $87-95$

de Martino, M; Chiarugi, A (2015). "Recent Advances in Pediatric Use of Oral Paracetamol in Fever and Pain Management". Pain and Ther. 4 (2): 149-168

Faruna, JA; Paul, ED;Dallatu, YA (2017) . Synthesis, Characterization and Evaluation of AntiInflammatory Activity of Acetaminophen Complexes of Copper (II) and Zinc (II) Ions,Int. J. of Bio. Mat. Res. 5(6): 78-83

Ghanem, CI; Pérez, MJ; Manautou, JE; Mottino, AD (2016). "Acetaminophen from liver to brain: New insights into drug pharmacological action and toxicity". Pharm. Res. 109: 119-31

Hochhauser, D (2014). Cancer and its Management. John Wiley \& Sons. 119.

Ledeti, I; Georgeta, S; Gabriela, V; Germaine, S; Titus, V; Lenuta-maria, S;Calin, P; Adriana, F (2013). Synthesis and Solid-State Characterization of $\mathrm{Zn}$
(II) Metal Complex with Acetaminophen, Rev. Chim. 64(10): 1127

Lee, WM (2017). Acetaminophen (APAP) hepatotoxicity-Isn't it time for APAP to go away?.J. of Hepatology. 67 (6): 1324-1331

Lewis, JH; Stine, JG (2013). "Review article: prescribing medications in patients with cirrhosis - a practical guide". Ali. Pharm. \&Ther.37 (12): 1132-56

Machado, GC; Maher, CG; Ferreira, PH; Pinheiro, MB; Lin, CW; Day, RO; McLachlan, AJ; Ferreira, ML (2015). "Efficacy and safety of paracetamol for spinal pain and osteoarthritis: systematic review and meta-analysis of randomised placebo controlled trials". BMJ (Clin. Res. Ed.).350: 1225

Maret, W; Sandstead, HH (2006). Zinc requirements and the risks and benefits of zinc supplementation. $J$. Trace Elem. Med. Biol. 20: 3-18.

McKay, GA; Walters, MR (2013). "Non-Opioid Analgesics". Lecture Notes Clinical Pharmacology and Therapeutics (9th ed.). Hoboken: Wiley.

Meremikwu, M; Oyo-Ita, A (2002). "Paracetamol for treating fever in children". The Coch. Database of Syst. Rev. (2): 3676

Milbury, PE; Richer, AC (2008). Understanding the Antioxidant Controversy: Scrutinizing the "fountain of Youth". Greenwood Publishing Group 99

Prasad, AS (1995). Zinc: an overview. Nutri. 11: 93-99

Prasad, AS; Beck, FW; Grabowski, SM; Kaplan, J; Mathog, RH (1997). Zinc deficiency: changes in cytokine production and T-cell subpopulations in patients with head and neck cancer and in noncancer subjects. Proc. Assoc. Am. Physicians. 109: 68-77

Reková, M; Vanura, P; Jedináková-Krízová, V (2009) "Determination of Protonation Constants and Stability Constants of Lanthanides with Derivative of $\mathrm{H}_{4}$ DOTA Complexes by the UV-VIS Spectrophotometry and Potentiometry", The Open Inorg. Chem. Jour., 3: 26

Russell, FM; Shann, F; Curtis, N; Mulholland, K (2003). "Evidence on the use of paracetamol in febrile children". Bull.of the World Health Org. 81 (5): 36772 . 
Sandstead, HH (1994). Understanding zinc: recent observations and interpretations. J Lab Clin. Med 124: $322-327$

Scottish Intercollegiate Guidelines Network (SIGN) (2008). "6.1 and 7.1.1" (PDF). Guideline 106: Control of pain in adults with cancer. Scotland: National Health Service (NHS)..Archived (PDF) from the original on 20 December 2010.

Tella, AC; Obaleye, JA (2009). Copper (II) complexes of 4,4-Diaminodiphenyl sulphone: Synthesis, Characterization and Biological Studies. E-Jour. of Chem, 6(51): 311-323

Tella, AC; Obaleye, JA (2010). "Metal-Chelator Therapy: Stability Constatnt of Transition metal complexes of Pyrimidine and Sulphonamide Drugs. Int. Chem. Sci. 8(3): 1675

The American Society of Health-System Pharmacists (2016). "Acetaminophen". Archived from the original on 5 June 2016. Retrieved 16 September 2016.
Tirmizi, SA; Sarwar, MH; Sarwar, WS; Anwar, W (2008). "Spectrophotometric study of stability constants of famotidine-Cu (II) complex at different temperatures", The Arab. J. for Sci. Eng. 34, (2A): $43-47$

Tirmizi, SA; Wattoo, FH; Wattoo, MHS; Sarwar, S; Memon, AN; Ghangro, AB (2012). "Spectrophotometric study of stability constants of cimetidine-Ni (II) complex at different temperatures", Arab. J. of Chemi, 5:309 -313

Viswanathan, AN; Feskanich, D; Schernhammer, ES; Hankinson, S (2008). "Aspirin, NSAID, and Acetaminophen Use and the Risk of Endometrial Cancer". CancerRes. 68 (7): 2507-2513

WaranyoupalinR; Wongnawa, S; Wongnawa, M; Pakawatchai, C; Panichayupakaranant, P; Sherdshoopongse, P (2009). Studies of complex formation between curcumin and $\mathrm{Hg}$ (II) by spectrophotometric method: A new approach to overcome peak overlap, Cent. Eur. J. Chem. 7(3): $388-392$ 